\title{
Adult pulmonary Langerhans cell histiocytosis revealed by central diabetes insipidus: A case report and literature review
}

\author{
JORGE LOURENÇO $^{1}$, CRISTINA FERREIRA ${ }^{2}$ and DANIELA MARADO ${ }^{1}$ \\ Departments of ${ }^{1}$ Internal Medicine and ${ }^{2}$ Pneumology, Coimbra University Central Hospital, 3000-075 Coimbra, Portugal
}

Received August 1, 2019; Accepted June 1, 2020

DOI: $10.3892 / \operatorname{mco} .2020 .2100$

\begin{abstract}
Langerhans cell histiocytosis ( $\mathrm{LCH})$ is a rare systemic and heterogeneous disease secondary to proliferation and diffuse infiltration of immature CD1a-positive dendritic cells, also known as Langerhans cells. LCH affects predominantly paediatric patients and is rarely diagnosed in adulthood. Despite its worldwide prevalence, most reported cases are found in the Japanese population. There is no consensus regarding treatment strategy due to the low incidence of this disease and the diversity of symptoms that appear. An integrative literature review was conducted based on the PubMed database using MeSH terms 'Langerhans', 'histiocytosis' and 'adult'. The present report describes a case of a successfully treated $\mathrm{LCH}$-induced central diabetes insipidus (uncommon presentation in adult patients) as well as an updated review of current evidence published on this matter.
\end{abstract}

\section{Introduction}

Langerhans Cell Histiocytosis $(\mathrm{LCH})$ is a rare disorder defined as a subgroup of myeloid malignancies consistent with disseminated infiltration and clonal proliferation of Langerhans cells, a specific type of immature CD1a-positive cells. These cells are named after Paul Langerhans, a 19th century young doctor who first identified them as epidermal cells of extracutaneous nerves using gold colloid staining technique. Actually, we now know that epidermal Langerhans cells are dendritic cells, a heterogeneous group of hematopoietic cells enriched in interface tissues throughout the body, mainly the skin, lungs, liver, bone marrow and lymphoid organs. These cells help regulate the immune system, presenting antigens to and activating antigen-specific T cells (1). LCH can appear at any age, but it is found usually during childhood, mainly between ages 2 and 3, with an annual incidence of 4.6 cases per 1 million children

Correspondence to: Dr Jorge Lourenço, Department of Internal Medicine, Coimbra University Central Hospital, Professor Mota Pinto Square, 3000-075 Coimbra, Portugal

E-mail: jorge.v.lourenco@gmail.com

Key words: histiocytosis, diabetes, polyuria, desmopressin, cytarabine under 15 years of age. The estimated incidence among adults is 1 to 2 cases per million, though LCH is probably underdiagnosed in this population. Race and ethnic background appear to influence the risk of developing $\mathrm{LCH}$, with a suspected higher risk among Caucasians, particularly in Northern Europe (2). LCH can present before, after, or along with other histologic cancers, frequently with shared mutations suggesting clonality, though it is not clear whether a history of LCH confers an increased risk of cancer (3).

The natural history of LCH consists of an insidious onset and intermittent remissive pattern, clinical manifestations of LCH vary from a self-limiting single bone disease to rapidly fatal multi-systemic one. The prognosis of $\mathrm{LCH}$ is closely related to age of onset (usually better outcome in adult patients), internal organs involvement and degree of functional impairment (3).

\section{Case report}

A 31-year-old woman was referred to Internal Medicine consultation because of a 2-month history of polydipsia (daily water intake around 8 liters per day) and polyuria, lately associated with exertional dyspnoea and episodic non-productive cough. She denied weight loss, anorexia and recent use of medication. She did not present emotional lability or other psychological distress. The patient was an active smoker, with familial history of multiple myeloma and Hodgkin disease. During physical examination, she had some fine crackles at pulmonary auscultation, with no other significant findings. Respiratory failure was excluded. During ambulatory investigation, the thoracic $x$-ray detected a diffuse a reticulonodular pattern (Fig. 1A) and further pulmonary assessment with thoracic CT scan was performed which showed bilateral bronchiectasis, interstitial fibrosis and bullous emphysema (Fig. 1B). Given these findings, a bronchofibroscopy was performed, which was eventually cancelled given her intolerance to fasting and her need to maintain water intake. Instead, it was decided for hospitalization in order to perform a surgical biopsy of the middle lobe and also to conclude the diagnostic workup related to her polydipsic and polyuric state. During hospitalization, the patient presented normal renal function (serum BUN of $54 \mathrm{mg} / \mathrm{dl}$ and serum creatinine of $0.94 \mathrm{mg} / \mathrm{dl}$ ), normal levels of adrenocorticotropic hormone (ACTH), and thyroid-stimulating hormone (TSH) as well as serum 
A

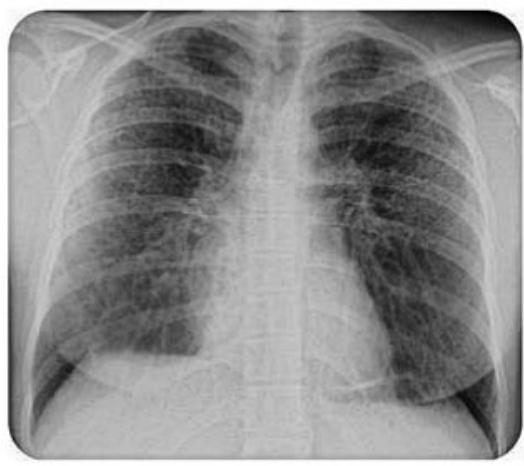

B

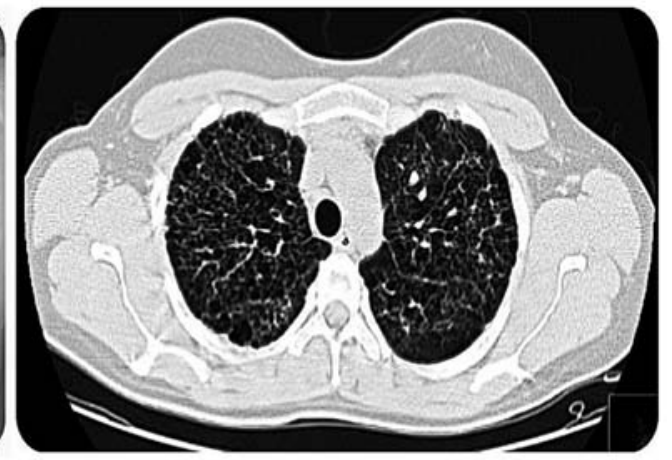

Figure 1. (A) Thoracic x-ray showing diffuse reticulonodular pattern and (B) thoracic CT image showing bilateral bronchiectasis, interstitial fibrosis and bullous emphysema.

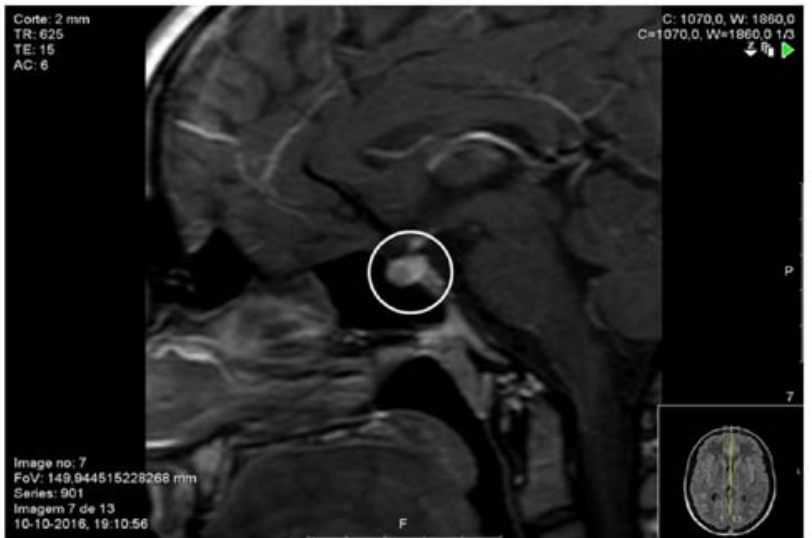

Figure 2. Brain MRI showing absence of posterior pituitary T1-weighted hypersignal and pituitary stalk thickening of $4 \mathrm{~mm}$ (normal value $<3.5 \mathrm{~mm}$ ).

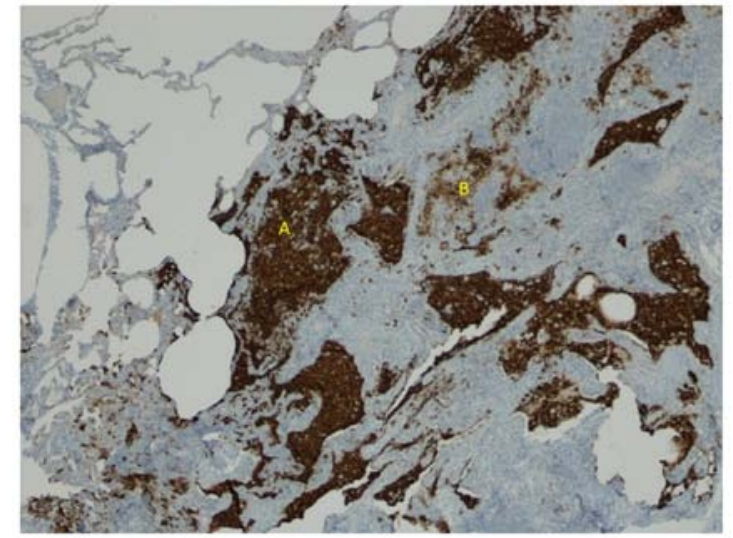

Figure 3. Lung histologic pattern: Langerhans cells-(A) CD1a and (B) protein S100 positivity. eletrolytes (sodium $137 \mathrm{mmol} / 1$, potassium $3.8 \mathrm{mmol} / \mathrm{l}$ and calcium $8.8 \mathrm{mg} / \mathrm{dl})$. Her biochemical profile also included SACE levels (serum angiotensin converting enzyme) of $47 \mathrm{U} / 1$ (normal value $<50 \mathrm{U} / 1$ and serum erythrocyte sedimentation rate of $20 \mathrm{~mm} / \mathrm{h}$ (normal value $<12 \mathrm{~mm} / \mathrm{h}$ ). She was submitted to a water deprivation test which lasted for $3 \mathrm{~h}$ and presented a serum sodium concentration ( $\mathrm{sNa}$ ) of $145 \mathrm{mmol} / \mathrm{l}$ with serum osmolality (SO) of $309 \mathrm{mOsm} / \mathrm{kg}$ and urine osmolality (UO) of $242 \mathrm{mOsm} / \mathrm{kg}$ ). There was a significant clinical response after administration of $10 \mu \mathrm{g}$ intra-nasal desmopressin (sNa of $138 \mathrm{mmol} / \mathrm{l}$ with $\mathrm{SO}$ of $272 \mathrm{mOsm} / \mathrm{kg}$ and UO of $831 \mathrm{mOsm} / \mathrm{kg}$ ), compatible with central diabetes insipidus (CDI). A cranial MRI was also performed, which showed absence of posterior pituitary T1-weighted hypersignal and pituitary stalk thickening of $4 \mathrm{~mm}$ (normal value $<3.5 \mathrm{~mm}$ ) (Fig. 2).

Meanwhile, the histologic exam of lung biopsy revealed a centrilobular emphysema with intra-alveolar macrophage desquamation, lymphoplasmocytic infiltration and juxtapleural confluence of Langerhans cells-CD1a and protein S100 positivity (Fig. 3).

It was assumed that the water balance disorder and the respiratory symptoms could be related to $\mathrm{LCH}$ affecting both brain and lungs. The patient was discharged maintaining treatment with desmopressin and underwent ambulatory staging PET-CT which confirmed pituitary and pulmonary uptake of ${ }^{18} \mathrm{FDG}$ (Fig. 4). After multidisciplinary evaluation, the patient began combination therapy with prednisone and cytarabine. The patient quit smoking and showed complete resolution of polyuria and polydipsia within the first month of treatment (oral desmopressin plus cytarabine/prednisone); she also noticed significant improvements over her respiratory symptoms 6 months later.

\section{Discussion}

The Histiocyte Society proposed a classification of different forms of histiocytosis, according to its cellular pattern, distinguishing 3 categories: (1) dendritic cells disorders (including LCH); (2) macrophage-related disorders; and (3) malignant histiocytosis (4). At present, LCH is classified as single-system (SS) and multisystem (MS) histiocytosis, the latter being divided in two groups depending on whether risk organs (RO) are involved (liver, lung, spleen and bone marrow) (5). The most important clinical LCH syndromes are eosinophilic granuloma (SS), Hand-Schüller-Christian disease (MS, RO-negative) and Letterer-Siwe disease (MS, RO-positive) (6). Some authors assume that histiocytic infiltration appears to be dominated by regulatory T-cell disfunction (which fail to neutralize the histiocytes), rather than an hyperproliferative process alone (7). There is still an active debate regarding LCH pathogenesis because it appears 

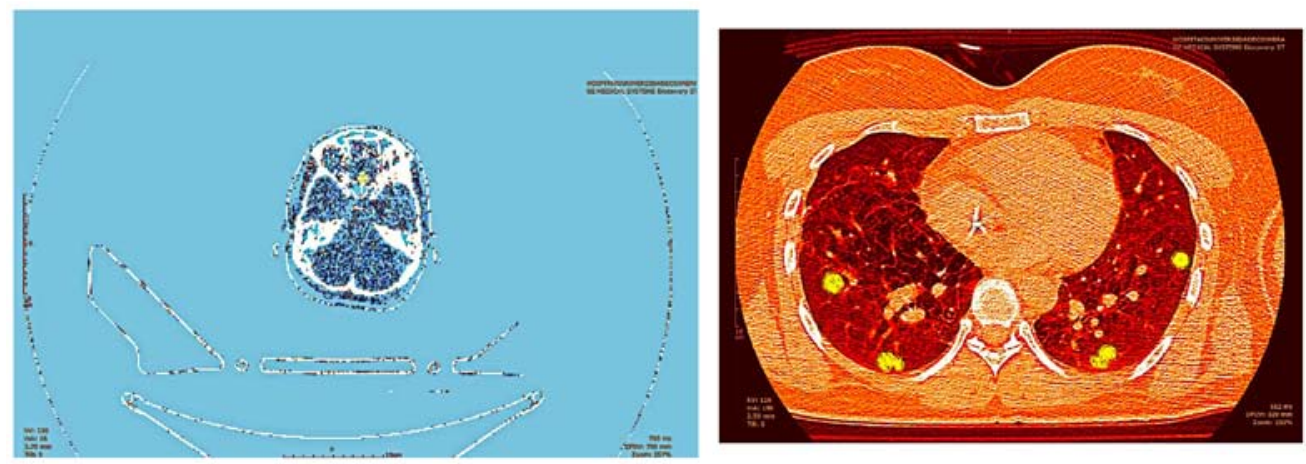

Figure 4. Reconstructed positron emission tomography-CT images showing increased pituitary and pulmonary 18Fluorodeoxyglucose uptake (yellow blur).

that this disease apparently presents features of both chronic inflammatory disease (presence of circulating pro-inflammatory cytokines such as TNF, IFN, IL-2, IL-12 and IL-17) (7) and neoplastic disease (presence of proto-oncogenic BRAF V600 and MEK-1 mutations) $(8,9)$.

The biopsy of one of the affected organs and its immunohistochemical (IHC) findings are crucial to confirm the diagnosis of LCH. The main differences between LCH and other forms of histiocytosis are based on specific profile markers such as CD1a and CD207 positivity as well as presence of Birbeck granules (pathognomonic cytoplasmic inclusions viewed by electron microscopy up to $40 \%$ of cases). The major differential diagnosis of adult LCH is Erdheim-Chester disease (ECD), a CD163 positive and CD1a negative polyostotic sclerosing form of histiocytosis, which often affects patients older than 40 years of age and could also develop CID (9).

In this article we present a rare case of LCH MS disease presenting with CDI before the beginning of the respiratory symptoms. Eventually, pulmonary assessment finally led to the diagnosis.

Despite being found in up to $30 \%$ of adult patients, it has been estimated that only $7 \%$ of pathologically-proven pulmonary $\mathrm{LCH}$ develop CDI and, in general, the latter is clinically evident afterwards $(10,11)$. There are also some reports of pituitary hormone deficiency in most severe cases $(12,13)$. The cranial MRI shows absence of physiologic high-T1 signal of neuro-hypophysis and thickening of pituitary stalk $(>3,5 \mathrm{~mm})(12,13)$. The diagnosis of CDI is made by water deprivation test or, if not tolerated, using hypersaline infusion $(0,05 \mathrm{ml} / \mathrm{kg} / \mathrm{min}$ for $2 \mathrm{~h})$. Usually, CDI does not respond to any $\mathrm{LCH}$-directed treatment and requires long-term replacement therapy with desmopressin (13). The respiratory symptoms described by the patient are usually seen in most cases of adult pulmonary LCH, mainly exertional dyspnoea, non-productive cough and pleuritic pain. High resolution thoracic CT scan typically shows interstitial, reticulonodular lesions and honeycombing pattern, which could contribute to mixed restrictive and obstructive patterns. In severe cases, pulmonary hypertension may develop $(14,15)$.

Our patient also reported a history of active smoking, which is described as a potential risk factor of $\mathrm{LCH}$. However, the role of cigarette smoke exposure in $\mathrm{LCH}$ pathogenesis and the impact of variable consumption in disease progression is yet to be fully understood. Smokers with $\mathrm{LCH}$ are also at high risk of developing recurrent pneumothorax (16). Some authors believe that smoking cessation appears to have significant prognostic impact in pulmonary LCH patients (16). Besides pulmonary and pituitary involvement, $\mathrm{LCH}$ is characterized by other important manifestations. Cutaneous and bone involvement are the most frequent signs of $\mathrm{LCH}$, found in $>50 \%$ of patients. This form of LCH could have the potential of spontaneous clinical remission, particularly in children (17). Bone damage seen in LCH is mainly related to osteolytic lesions, being the jaw most affected in adults (18). The osteolytic lesions seen in $\mathrm{LCH}$ are due to osteoclast-like activity of multinuclear giant cells $(18,19)$ and different symptoms may develop depending on anatomic location. In fact, patients could develop conduction deafness (mastoid involvement), exophthalmia (retro-orbicular involvement) and paraplegia (vertebral involvement) $(20,21)$. The PET-CT and axial MRI are most useful for further defining skeletal lesions and could also be used to evaluate treatment response (21).

There is no consensus regarding $\mathrm{LCH}$ management in adult patients. In general, the choice of therapeutic regimen is based on disease severity (22). Cutaneous form of LCH patients could even benefit from ultraviolet phototherapy $(23,24)$. The Histiocyte Society and Japan LCH Study Group have been conducting several prospective, randomized control trials that studied the effect of several chemotherapy regimens for LCH $(25,26)$. The LCH-III study was designed for establishment of a MS LCH treatment strategy, which consisted of oral prednisone daily and intravenous vimblastine weekly for 6 weeks and repeat the same treatment for another 6 weeks if disease remains active (27).

Patients in remission after 6-week of induction therapy should begin maintenance therapy with a 12-month triple regimen, composed by daily oral 6-mercaptopurine and oral prednisone associated with weekly intravenous vimblastine. Patients with multifocal bone disease and/or central nervous system lesions should be treated with oral prednisone daily and intravenous vimblastine weekly for 6 months. The addition of methotrexate in $\mathrm{LCH}$ treatment is not recommended in current practice (27). Despite these recommendations, our patient began combination therapy of cytarabine with oral prednisone, according to our clinical experience and treatment protocol developed in our department. This regimen has been studied in the last few years with promising results. Simko et al revised data of patients treated with cytarabine for both naïve and recurrent LCH at Texas Cancer Center from 2005-2013. 
They concluded that $88 \%$ of $\mathrm{LCH}$ achieved remission by the end of first year of treatment and $59 \%$ of patients with recurrent LCH showed significant improvement in the first three months of therapy (28).

In a retrospective study, there was a significant survival impact of cytarabine after the first year of remission, with less toxicity compared with classic regimen vinblastine/prednisone (29).

Thus, we present a case report that also reaffirms the therapeutic potential of this alternative treatment as a first contender to dethrone vinblastine/prednisone. There have been also some positive results of pulmonary $\mathrm{LCH}$ patients being treated with cladribine, in monotherapy or in association with systemic glucocorticoids (30). The ongoing LCH-IV study, a prospective international treatment protocol sponsored by Dana-Farber Cancer Institute will investigate the efficiency of second line treatment with cytosine arabinoside and cladribine (2-chlorodeoxyadenosine) in patients who did not respond to standard first-line prednisone and vinblastine. In 2017, FDA approved vemurafenib for ECD with BRAF V600 mutations. There are some reports of $\mathrm{LCH}$ patients who presented this mutation that showed clinical improvement maintained after 4 months of treatment with vemurafenib, even though persistent disease activity was still observed. More clinical trials are needed to validate this treatment strategy in $\mathrm{LCH}$ patients presenting BRAF V600 mutations $(31,32)$. Bone marrow transplantation or reduced-intensity condition stem cell transplantation has shown promise as effective salvage therapy in $\mathrm{LCH}$ patients with a very poor prognosis (rapid disease progression, refractory to conventional treatment, or with disseminated risk-organ involvement) $(33,34)$.

In conclusion, the advances over basic knowledge on $\mathrm{LCH}$ poses a huge challenge in clinical practice particularly over patient care.

Given its low prevalence, there is still the need of further clinical trials regarding innovative and targeted therapies that could be used as an alternative to standard care.

There is quite expectations regarding LCH-IV results, which could consolidate LCH treatment recommendations for refractory disease.

\section{Acknowledgements}

Not applicable.

\section{Funding}

No funding was received.

\section{Availability of data and materials}

Data sharing is not applicable to this article, as no datasets were generated or analyzed during the current study.

\section{Authors' contributions}

JL concieved and designed the manuscript. JL,CF and DM acquired the data. CF and DM drafted the manuscript and revised it critically for important intellectual content. All authors read and approved the final manuscript. All authors agreed to be accountable for all aspects of the work in ensuring that questions related to the accuracy or integrity of any part of the work are appropriately investigated and resolved.

\section{Ethics approval and consent to participate}

Not applicable.

\section{Patient consent for publication}

The patient provided written informed consent for the publication of any associated data and accompanying images.

\section{Competing interests}

The authors declare that they have no competing interests.

\section{References}

1. Stockschlaeder M and Ssucker C: Adult langerhans cell histiocytosis. Eur J Haematol 76: 363-368, 2006.

2. WHO Classification of Tumours of Haematopoietic and Lymphoid Tissue. IARC, Lyon, pp470-472, 2017.

3. Lian C, Lu Y and Shen S: Langerhans cell histiocytosis in adults: A case report and review of literature Oncotarget 7: 18678-18683, 2016.

4. Histiocytosis syndromes in children. Writing group of the histiocyte society. Lancet 1: 208-209, 1987.

5. Favara BE, Feller AC, Pauli M, Jaffe ES, Weiss LM, Arico M, Bucsky P, Egeler RM, Elinder G, Gadner H, et al: Contemporary classification of histiocytic disorders. The WHO committee on histiocytic/reticulum cell proliferations. Reclassification working group of the histiocyte society. Med Pediatr Oncol 29: 157-166, 1997.

6. Titgemeyer C, Grois N, Minkov M, Flucher-Wolfram B, GattererMenz I and Gadner H: Pattern and course of single-system disease in langerhans cell histiocytosis data from the DAL-HX 83- and 90-study. Med Pediatr Oncol 37: 108-114, 2001.

7. Hutter $\mathrm{C}$ and Minkov $\mathrm{M}$ : Insights into the pathogenesis of Langerhans cell histiocytosis: The development of targeted therapies. Immunotargets Ther 5: 81-91, 2016.

8. Tatsuno M, Shioda Y, Iwafuchi H, Yamazaki S, Iijima K, TakahashiC, Ono H, Uchida K, Okamura O, Matubayashi M, et al: BRAF V600 mutations in langerhans cell histiocytosis with a simple and unique assay. Diagn Pathol 11: 39, 2016.

9. Harmon CM and Brown N: Langerhans cell histiocytosis: A clinicopathologic review and molecular pathogenetic update. Arch Pathol Lab Med 139: 1211-1214, 2015.

10. Kaltsas GA, Powles TB, Evanson J, Plowman PN, Drinkwater JE, Jenkins PJ, Monson JP, Besser GM and Grossman AB: Hypothalamo-pituitary abnormalities in adult patients with langerhans cell histiocytosis: Clinical, endocrinological and radiological features and response to treatment. J Clin Endocrinol Metab 85: 1370-1376, 2000.

11. Choi YS, Lim JS, Kwon W, Jung SH, Park IH, Lee MK, Lee WY, Yong SJ, Lee SJ, Jung YR, et al: Pulmonary langerhans cell histiocytosis in an adult male presenting with central diabetes insipidus and diabetes mellitus: A case report. Tuberc Respir Dis (Seoul) 78: 463-468, 2015.

12. Choi JE, Lee HR, Ohn JH, Moon MK, Park J, Lee SJ, Choi MG, Yoo HJ, Kim JH and Hong EG: Adult multisystem langerhans cell histiocytosis presenting with central diabetes insipidus successfully treated with chemotherapy. Endocrinol Metab (Seoul) 29: 394-399, 2014.

13. Hong ES, Ohn JH, Kim JH, Hwang-Bo Y, Kim JJ, Kwon JH, Lee JW, Choi SY, Lee EK, Cho SW, et al: Clinical characteristics of langerhans cell histiocytosis with hypothalamo-pituitary involvement. Endocrinol Metab 26: 38-43, 2011.

14. Wei P, Lu HW, Jiang S, Fan LC, Li HP and Xu JF: Pulmonary langerhans cell histiocytosis: Case series and literature review. Medicine (Baltimore) 93: 1-7, 2014. 
15. Tazi A, de Margerie C, Naccache JM, Fry S, Dominique S, Jouneau S, Lorillon G, Bugnet E, Chiron R, Wallaert B, et al: The natural history of adult pulmonary langerhans cell histiocytosis: A prospective multicentre study. Orphanet J Rare Dis 10: 1-10, 2015.

16. Ninaber M, Dik H and Peters E: Complete pathological resolution of pulmonary Langerhans cell histiocytosis. Respirol Case Rep 2: 76-78, 2014.

17. Simko SJ, Garmezy B, Abhyankar H, Lupo PJ, Chakraborty R, Lim KPH, Shih A, Hicks MJ, Wright TS, Levy ML, et al: Differentiating skin-limited and multisystem langerhans cell histiocytosis. J Pediatr 165: 990-996, 2014.

18. Stull MA, Kransdorf MJ and Devaney KO: Langerhans cell histiocytosis of bone. Radiographics 12: 801-823, 1992.

19. Kim SH and Choi MY: Langerhans cell histiocytosis of the rib in an adult: A case report. Case Rep Oncol 9:83-88, 2016.

20. Song YS, Lee IS, Yi JH, Cho KH, Kim DK and Song JW: Radiologic findings of adult pelvis and appendicular skeletal langerhans cell histiocytosis in nine patients. Skeletal Radiol 40 $1421-1426,2010$

21. Christopher Z, Binitie O, Henderson-Jackson E, Perno J and Makanji RJ: Langherhans cell histiocytosis of bone in an adult: A case report. Radiol Case Rep 13: 310-314, 2018

22. Aricò M, Girschikofsky M, Généreau T, Klersy C, McClain K, Grois N, Emile JF, Lukina E, Juli ED and Danesino C: Langerhans cell histiocytosis in adults: Report from the international registry of the histiocyte society. Eur J Cancer 39: 2341-2348, 2003.

23. Do J, Lee J and Kim Y: Successful treatment of cutaneous langerhans' cell histiocytosis with targeted narrowband ultraviolet B phototherapy in an infant. Clin Exp Dermatol 34: e280-e281, 2009

24. Vogel C, Aughenbaugh W and Sharata H: Excimer laser as adjuvant therapy for adult cutaneous langerhans cell histiocytosis. Arch Dermatol 144: 1287-1290, 2008.

25. Satter E and High W: Langerhans cell histiocytosis: A review of current recommendations of the histiocyte society. Pediatr Dermatol 25: 291-295, 2008.

26. Gadner H: Treatment of adult-onset langerhans cell histiocytosis-is it different from the pediatric approach? Ann Oncol 21: $1141-1142,2010$
27. Gadner H, Minkov M, Grois N, Pötschger U, Thiem E, Aricò M, Astigarraga I, Braier J, Donadieu J, Henter JI, et al: Therapy prolongation improves outcome in multisystem langerhans cell histiocytosis. Blood 121: 5006-5004, 2013.

28. Simko S, McClain K and Allen C: Up-front therapy for $\mathrm{LCH}$ : Is it time to test an alternative to vinblastine/prednisone? $\mathrm{Br} \mathrm{J}$ Haematol 169: 299-301, 2015.

29. Cantu MA, Lupo PJ, Bilgi M, Hicks MJ, Allen CE and McClain KL: Optimal therapy for adults with langerhans cell histiocytosis bone lesions. PLoS One 7: e43257, 2012.

30. NassEr M, Traclet J and Cottin V: Effect of cladribine therapy on lung cysts in pulmonary langerhans cell histiocytosis. ERJ Open Res 4: 00089-2017, 2018.

31. Haroche J, Cohen-Aubart F, Emile JF, Arnaud L, Maksud P, Charlotte F, Cluzel P, Drier A, Hervier B, Benameur N, et al: Dramatic efficacy of vemurafenib in both multisystemc and refractory erdheim-chester disease and langerhans cell histiocy tosis harbouring the BRAF V600E mutation. Blood 121: 1495-1500, 2013

32. Abla $\mathrm{O}$ and Weitzman S: Treatment of langerhans cell histiocytosis: Role of BRAF/MAPK inhibition. Hematology Am Soc Hematol Educ Program 2015: 565-570, 2015.

33. Steiner M, Matthes-Martin S, Attarbaschi A, Minkov M, Grois N Unger E, Holter W, Vormoor J, Wawer A, Ouachee M, et al: Improved outcome of treatment-resistant high-risk langerhans cell histioytosis after allogenic stem cell transplantation with reduced-intensity conditioning. Bone Marrow Transplant 36: 215-225, 2005.

34. Kesik V, Citak C, Kismet E, Koseoglu V and Akyuz C Hematopoietic stem cell transplantation in langerhans cell histiocytosis: Case report and review of the literature. Pediatr Transplant 13: 371-374, 2009

This work is licensed under a Creative Commons Attribution-NonCommercial-NoDerivatives 4.0 International (CC BY-NC-ND 4.0) License. 